Article

\title{
Evaluating the Effect of Perceived Value of Ecosystem Services on Tourists' Behavioral Intentions for Aogu Coastal Wetland
}

\author{
Meng-Tsung Lee ${ }^{1}$, Jen-Ming Liu ${ }^{2}$ and Elaine Q. Borazon ${ }^{3, *(\mathbb{D}}$ \\ 1 Department of Marine Leisure Management, College of Marine Commerce, National Kaohsiung University \\ of Science and Technology, Kaohsiung 80778, Taiwan; masonlee@nkust.edu.tw \\ 2 Department of Fisheries Production and Management, College of Hydrosphere Science, National Kaohsiung \\ University of Science and Technology, Kaohsiung 80778, Taiwan; ljm0723@nkust.edu.tw \\ 3 IGPEHD, College of Social Sciences, National Sun Yat-sen University, Kaohsiung 80424, Taiwan \\ * Correspondence: elaineqborazon@mail.nsysu.edu.tw
}

Received: 18 June 2020; Accepted: 29 July 2020; Published: 2 August 2020

\begin{abstract}
This research empirically tested the effect of perceived value of ecosystem services on tourists' intentions to revisit the Aogu coastal wetland in Taiwan. Data were collected using a structured survey and structural equation modeling was then done to test the research hypotheses. Based on the data collected from 230 tourists in the Aogu coastal wetland, the perceived value of ecosystem services of wetland has a positive effect on tourists' environmental concerns and friendly environmental behavior. Results also indicate that tourists' environmental concern has a positive effect on friendly environmental behavior and tourists' friendly environmental behavior has a positive effect on revisit intention to the Aogu coastal wetland. However, the effects of perceived value of ecosystem services and tourists' environmental concerns on revisit intention were not found to be significant in this study. These results have implications for tourism management of coastal wetlands and the increase in revisit intentions of tourists.
\end{abstract}

Keywords: ecosystem service; environmental concerns; friendly environmental behavior; revisit intention; Aogu coastal wetland

\section{Introduction}

The rapid global economic development and rise of individual incomes have significantly increased the demands for travel and leisure activities. According to the report published by the World Tourism Organization, international tourist arrivals increased by $4.0 \%$ in 2019 [1], but are expected to fall by $20 \%-30 \%$ due to the global pandemic [2]. In 2019, the travel and tourism sector accounted for $10.3 \%$ of the global GDP and generated $330 \mathrm{M}$ jobs [3]. Specifically, in Taiwan, when the direct link with mainland China was established, the Taiwan government placed more efforts on the development of the tourism industry. Thus, the tourism industry's revenue in 2019 had reached US $\$ 37.7$ billion and contributed $6.4 \%$ of the total GDP, signifying a $7.6 \%$ growth from the previous year [4].

However, the rapid development of tourism activities could lead to a potential impact on the environment. As the awareness of environmental protection increased, the issue of sustainable tourism has become increasingly important in academic and practical fields. Tourism industries have been challenged to adopt sustainable environmental practices as their way to achieve competitive advantage. Moreover, some consumption habits directly or indirectly affect the environment. Thus, according to Fransson and Garling [5], interventions are necessary but for these interventions to be effective, there should be an increase in knowledge on the impact of environmental destruction to future generations and environmental concern or environmental emotions. The aforementioned 
authors defined environmental concern as the assessment of one's attitude or behavior and taking into consideration their effects on the environment. The theory of planned behavior, which claims that behaviors are determined by behavioral intentions [6], and the expectancy-value theory, which posits that behavioral motivations rely on the personal evaluation of the intended outcome and the expectations that the behavior will lead to an outcome [7], serve as the theoretical framework to comprehend what influences repurchase intentions of customers. Aside from environmental emotions, this study treated perceived value as another determinant of behavioral intentions. Perceived value is defined as the feelings visitors gained after availing of the products and services of the destination [8].

Ecotourism has been proven to contribute to both environmental conservation and economic development, and hence has gained considerable attention in the field of tourism research. It focuses on giving experiences in natural areas, while emphasizing protection and conservation of the environment [9]. Wetlands, for example, are one of the major ecosystems supporting people and wildlife and has become an ecotourist destination. Wetlands comprise approximately $6 \%$ of the total landscape and their importance is greater than their area from the regional to global scale [10]. In terms of global economic importance, wetlands are valued at $\$ 15$ trillion [11]. However, in the past 100 years, 60 percent of the wetlands globally had been destroyed due to pollution, drainage for agriculture, peat extraction, and groundwater pumping [12].

In order to attain sustainable tourism, it is imperative that government, industry, community, and tourists be involved. Friendly environmental behavior of tourists prevents or limits the damage to the ecological environment. There are few studies, however, on the exploration of the link between the perceived value of ecosystem services, friendly environmental behavior, and revisit intentions. Accordingly, this study aimed to investigate how the perceived value of ecosystem services, environmental emotion or concern, and friendly environmental behavior affect tourists' revisit intention to the Aogu coastal wetland in Taiwan. Section 1 introduces the rationale and objective of the research. Section 2 presents the theoretical background and literature review, including the hypotheses and the conceptual framework. Section 3 describes the research methodology, sampling and questionnaire design, and data analysis. Section 4 presents the results and discussion, while the conclusions and implications are in the final section.

\section{Theoretical Foundation, Literature Review, and Hypotheses Development}

According to Ajzen [6], the theory of planned behavior (TPB) claims that individuals make logical decisions on certain behaviors by evaluating the available information, where the central element is the intention to act. Behavioral intentions are affected by the probability that the behavior will lead to the results being expected and the costs and benefits of the said results [13]. Thus, intentions are said to capture the motivational factors that influence how a person behaves, and have three determinants: attitude towards the behavior, social norms or social pressures, and the degree of perceived behavioral control [14]. Attitude is the positive or negative evaluation of a subject or attitude object. It includes affection or emotion, cognition, and behavior and interrelation effects exist [15]. Social norms are the perceived social pressure that affect how a person would act on a certain behavior. Lastly, perceived behavioral control is a person's judgment on whether a behavior shall be acted or not acted. The greater the perceived behavioral control, the greater the intention to act a certain behavior $[14,16]$. The attitude of the persons, their social norms or social pressures, and the perceived behavioral control indirectly affect behavior through behavioral intentions [6,17]. Previous tourism-related studies [18-20] have demonstrated that the determinants of intention, attitude towards the behavior, social norms or social pressures, and the perceived behavioral control all increase when the tourists are aware of environmental problems, which then increases their intention to do pro-environmental actions.

The expectancy theory posits that individuals will exhibit a certain behavior because of the outcome expected from that behavior [21]. Thus, the motivation for the behavior relies on the personal evaluation of the expected benefit and the anticipation that the efforts will cause the outcome [22]. Moreover, the expectancy-value theory claims that individuals will first create a belief about the 
behavior or object by assessing the different attributes related to the object or behavior [7]. These beliefs and values can be summarized as attitude, which influences behavior [21].

Thus, the theory of planned behavior and the expectancy-value theory all agree that the evaluation of an object or behavior influences actual behavior. Thus, in the context of ecotourism sites, the tourists' evaluation of their experiences influences their feeling towards the site, its products, and services [23].

Wetlands, which is at the boundary between the aquatic area and the terrestrial area, are said to be the most productive ecosystems. Aside from providing human needs such as food and water, it also became a way for coast protection. It plays an important role in controlling flood, cleaning water, carbon sink and source, protecting shorelines, storm protection, cultural value, raw material for medicines, recreation areas, habitat, and as a refuge for migrating birds. In addition, wetlands' ecosystems also bring in opportunities for ecotourism, especially in developing countries [24,25]. Wetland tourism lets tourists experience the beauty of nature without harming or damaging it, and in return, tourists provide income for the local community and lend support for conserving the environment [26]. Hence, ecosystem services revolve around the natural ecosystems and species in order to meet the survival of human ecology and biodiversity processes and conditions. Boyd and Banzhaf [27] defined ecosystem services as those parts of nature consumed or enjoyed leading to human well-being. Ecosystem services offered by wetlands can be categorized as regulating services or the benefits gained from regulating the various processes in the ecosystem (i.e., climate regulation, air quality regulation, erosion resources and fresh water, and water regulation), habitat or supporting services or the services necessary for creating other ecosystem services (i.e., soil formation, primary production, photosynthesis, nutrient cycling, and water cycling), provisioning services or the raw materials gained from ecosystems (i.e., food, genetic resources, fuel, biochemical, pharmaceuticals, natural medicines, and ornamental resources), and cultural services or the nonmaterial benefits gained from the ecosystems through the development of cognitive abilities, enrichment of the spirit, experience of reflection, and recreation (i.e., education, tourism) [11].

Drawing on the TPB, expectancy-value theory, and previous tourism studies, Figure 1 shows a conceptual framework showing the proposed relationships among the latent factors. Perceived value is defined as the perceived benefits by the customers or guests and varies according to context [28,29]. Revisit intention is the probability that a customer or guest will repeat the activity or return again to the destination previously visited [30]. Friendly environmental behaviors refer to the importance a visitor or guest places on ecological issues [31]. Environmental emotions or concerns refer to a sense of belonging and a sense of duty towards the environment [32]. TPB explains various human behaviors and can be extended by including specific constructs in the tourism context [6,33], and in this study, using an ecotourism context. Tourism researchers claim that by extending TPB, it would be able to better predict behavioral intentions and provide an avenue to expand the said theory [34]. Thus, this study contributes to literature by testing TPB and expectancy-value theory in revisit intentions in an ecotourism context. Previous studies [34,35] have shown the worth of TPB in human behaviors in the hospitality and tourism industry. The study by Goh, et al. [36] has expanded the theory by adding pro-environmental values as an ecological paradigm into the TPB. The expectancy-value theory has been widely utilized in education-related research [37-39] and tourism studies [40]. To the author's knowledge, only the study of Kiatkawsin and Han [41] and Chiu, Lee and Chen [21] have applied the said theory on environment-related research. Considering the theories' strong predictive ability for revisit intentions, this study adds environmental emotions and friend environmental behavior as essential factors reflecting an ecotourist destination to gain insights on revisit intentions. The bases for the proposed linkages are provided below. 


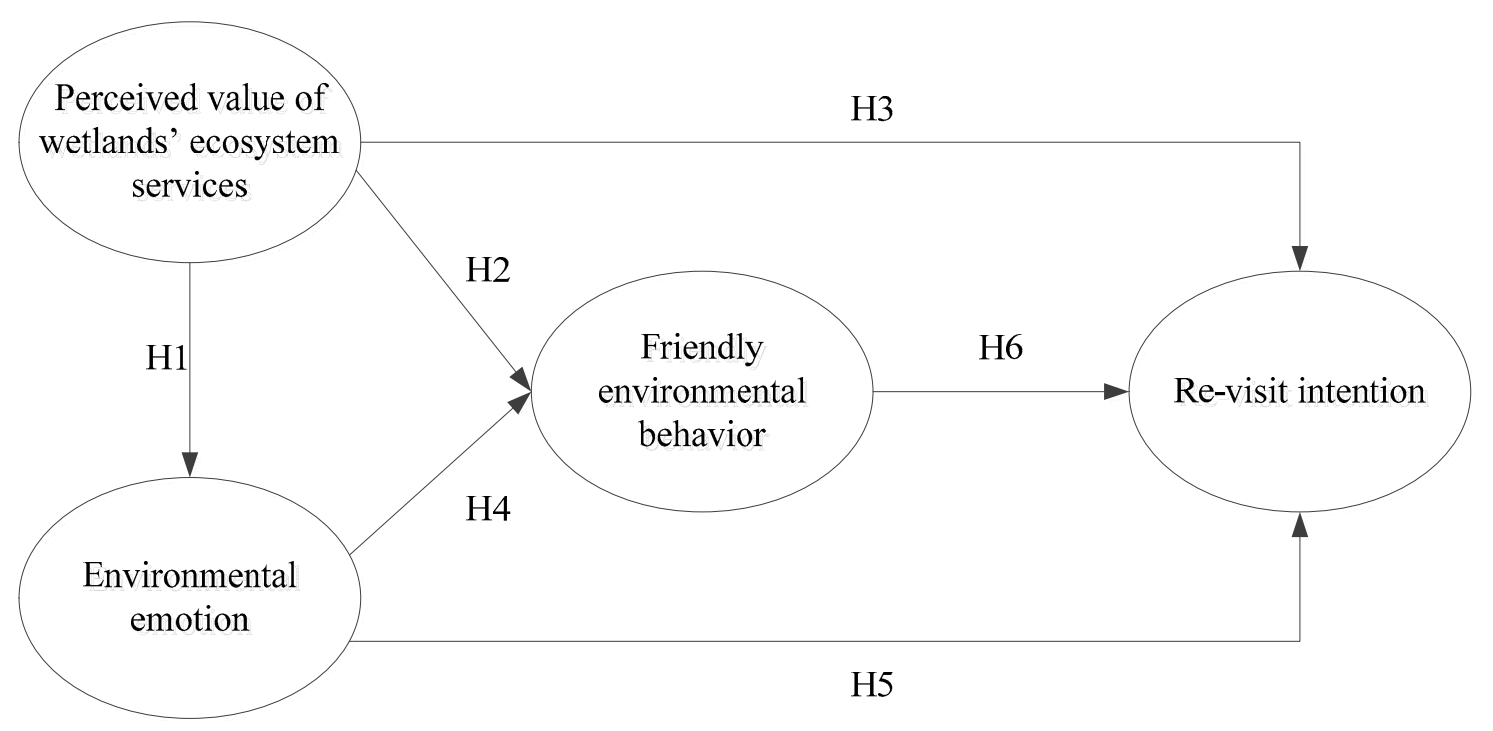

Figure 1. Conceptual model $\left({ }^{*} \mathrm{H}=\right.$ Hypothesis $)$.

According to Chiu, Lee and Chen [21], it is not the genetic characteristics but the travel experience of the tourists that affect their behavior towards the environment. Moreover, the tourists' overall perceived value, which comprises of the evaluation of service, quality, price, and products and the overall assessment of their experience would be a key to understanding customer behavior [42]. Perceived value, in the context of tourism, is defined as the value associated by tourists to the experience as a result of how the tourist interprets, receives, selects, and organizes the information from the various activities engaged by the tourist [43]. Value is the costs and benefits seen by the visitors in relation to the intangible and tangible aspect of a destination [44]. In tourism studies, perceived value is a personal assessment of the travel services, such as the service quality, emotions, and social aspects [45]. The higher the perceived value of the tourist to the ecotourism travel experience, the more they will identify with the environment, which can influence their concern and sensitivity towards it [21]. Thus, when visitors perceive some benefits of the ecosystem or destination, it will positively influence their emotions or feelings or concern for the environment. Thus, it is proposed that:

Hypothesis 1. Perceived value of wetlands' ecosystem services has a positive effect on tourists' environmental emotion.

Nature-based tourism, or 'ecotourism', is experiencing nature at its purest. It also instills learning, responsibility, and environmental awareness to tourists, while generating income for the local economy [42]. The environmental knowledge that tourists gained from their travel experience can positively affect and lead to shaping people's attitudes and behaviors towards conservation and sustainability [46]. Aside from providing ecosystem services for humans, like food and raw material production, wave reduction, hydrological climate and gas regulation, wetland ecosystems also provide income, especially for fishermen and those in the agriculture sector, and support wildlife, primarily the survival of migratory birds and other organisms [47]. Tourism managers also play a part in providing high quality recreation in order to reduce the environmental impact of tourism in the tourism area, while at the same time, educating and raising environmental concerns. In addition to that, for sustainability in nature-based tourism to ensue, tourists should be able to nurture friendly environmental behavior [48]. The study by Han, et al. [49] showed that friendly environmental behavior is somehow driven by perceived value of a certain tourism destination. Friendly environmental behavior, in the context of tourism, can be defined as the activities that tourists engage in so as to minimize the negative effect on the environment and thereby promote the protection of the environment $[21,50]$. Thus, it is proposed that: 
Hypothesis 2. Perceived value of wetlands' ecosystem services has a positive effect on tourists' friendly environmental behavior.

According to Chaulagain, et al. [51], the perceived value of a destination affects intention of tourists to travel. In a study conducted by Wang, et al. [52] in China, tourist experiences (activities, resources conditions, services, personnel, and overall management of tourism area) affected the decision-making of travelers (post-trip behavioral intention). Perceived value influences satisfaction of tourists, and in turn affects behavioral intention, which includes revisit intention and recommendation [53,54].

In relation to the theory of planned behavior and expectancy-value theory, an individual's attitude affects a person's behavioral intention (includes revisit intention). Behavioral motivation depends on the individual evaluation and the expectation that the efforts will lead to a certain outcome. Likewise, in the context of tourism, tourists' favorable evaluations (on services, environment, people, etc.) will influence their intention to revisit a certain tourism area. In addition to that, the three factors under $\mathrm{TPB}$, which are attitude towards the behavior, social pressures, and the perceived behavioral control, affect intention, may it be negative or positive [55]. Previous studies $[49,56]$ have supported the causal effects of these factors on revisit intentions. Thus, it is proposed that:

Hypothesis 3. Perceived value of wetlands' ecosystem services has a positive effect on tourists' revisit intention to the Aogu coastal wetland.

Emotion, behavior, and environment are connected to each other. The surrounding environment can affect a person's emotion, which then influences human behavior [57]. According to Su, et al. [58], satisfaction, recollection, and environmentally responsible behavior is a response to the overall tourism experience (which includes emotion). Evaluation of tourist experiences about a tourism site/area greatly depends on the feelings they make out during the whole stay, and that positive feelings will then also benefit the tourism site with positive feedback and impressions [21]. The study of Zeppel [59] on marine wildlife tourism showed that services and experiences that incite positive emotions and promote environmental awareness can trigger environmentally friendly/responsible behavior and actions. It also shows the destination plays a part in stimulating emotional experience which will then lead to a positive (or negative) response. Concern and respect (environmental sensitivity) of tourists affects both affection and attitude of tourists, which then leads to exhibiting friendly environmental behavior [60]. Thus, it is proposed that:

Hypothesis 4. Environmental emotion has a positive effect on friendly environmental behavior.

There are quite a number of studies on restaurants, countries, and tourist destinations in relation to emotions post-visit and how it affects intention to revisit $[57,61,62]$. Under memorable tourism experiences (MTEs), there are those of the affective experiences (of emotional nature). This type of experience builds a bond between tourists and the destination [57]. The study by Servidio and Ruffolo [63] showed that different emotions, may they be positive or negative, are linked to tourists'/consumers' behavior and decision making. When tourists are able to have positive environmental emotion and become concerned with environmental protection due to the environmental knowledge gained from the tourist visit, they then have the motivation and intention to revisit the place $[46,64]$ and exhibit friendly environmental behavior. Previous studies [18-20] also showed that the determinants of intention, attitude towards the behavior, social norms or social pressures, and perceived behavioral control all increase when aware of environmental problems, which then increases their intention to do pro-environmental actions. Thus, it is proposed that:

Hypothesis 5. Environmental emotion has a positive effect on tourists' revisit intention to the Aogu coastal wetland. 
Hypothesis 6. Friendly environmental behavior has a positive effect on tourists' revisit intention to the Aogu coastal wetland.

As mentioned, the perceived value of an ecotourist destination drives friendly environmental behavior [49], which then influences future behavior of revisiting the destination. When consumers or visitors are able to create a positive attitude, which then influences behavior, it has a positive influence on future purchase intention and purchasing behavior [65]. Moreover, when tourists experience a positive environmental emotion or concern, they show friendly environmental behavior, which then influences their motivations to revisit the destination $[46,64]$. Thus, it is hypothesized that:

Hypothesis 7. Friendly environmental behavior mediates the effect between perceived value of wetlands' ecosystem services and revisit intention to the Aogu coastal wetland.

Hypothesis 8. Friendly environmental behavior mediates the effect between environmental emotion and revisit intention to the Aogu coastal wetland.

\section{Methodology}

\subsection{Questionnaire Design}

A self-administered questionnaire (see Appendix A for the list of items used) was conducted in 2018 from March to July in order to collect the empirical data. To ensure the reliability and validity of the survey data, this study designed the questionnaire following Iacobucci and Churchill [66] methods. Measures for perceived value of ecosystem service (regulating service, cultural service, support service, provisioning service), environmental emotion or concern, friendly environmental behavior (direct and indirect), and revisit intention used in this study were drawn from previous studies, and to ensure their validity, they were discussed with three ecotourism executives and experts. Indirect friendly environmental behavior refers to those behaviors that indirectly impact the environment, while direct friendly behaviors are those behaviors that affect the environment directly [67].

A pretesting and a pilot study in the last two weeks of February 2018 were conducted to improve the questionnaire design and to enhance the validity and reliability of the survey instrument. The pilot questionnaire was answered by 60 tourists in the Aogu coastal wetland. Finally, fifty-two pilot questionnaires were returned and of those, no particular confusion with respect to format or question type was found. Thus, the said questionnaires were considered usable and potentially eligible for data analysis. Each item was assessed using a five-point Likert scale, with values from 1 (strongly disagree) to 5 (strongly agree).

\subsection{Sampling}

This study empirically examined how the perceived value of ecosystem service, environmental emotion, and friendly environmental behavior affect tourists' revisit intention to the Aogu coastal wetland (see Figure 2 below). A nonprobability and convenient sampling method was used to collect the research data. Three hundred questionnaires were delivered in the tourist service center of the Aogu Wetland and Forest Park in Taiwan. A total of 236 questionnaires from tourists were collected, of which six questionnaires were not included because some items did not have complete responses. The total number of usable responses was thus 230 , giving an overall response rate of $76.7 \%$. 


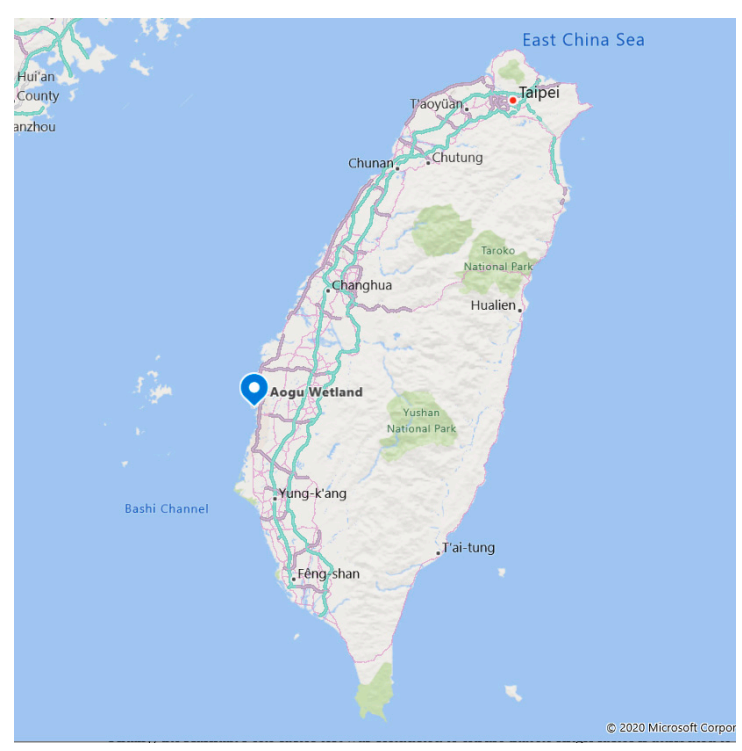

Figure 2. Location map of Aogu Wetlands in Taiwan [68].

Due to the fact that the data were from single informants, common method variance (CMV) might be a threat to the validity of the research results [69]. Thus, both procedural and statistical tests were done to determine this potential problem in the study. With respect to procedural remedies, the respondents were assured of anonymity so as to encourage them to answer as honestly as possible. Finally, the Harman's one-factor test was conducted to ensure that no single factor is attributed to the majority of the covariance between the criterion and the predictor variables. Results indicating seven factors with eigenvalues of greater than 1 were identified and explained $68.9 \%$ of the total variances. The first single factor only accounted for $36.6 \%$ of the total variances, indicating the absence of a general factor that accounts for the majority of the variances of the items.

\subsection{Data Analysis}

Following Anderson and Gerbing [70] suggestion, this study used a two-step structural equation modeling (SEM) method to test the measurement theory and the research hypotheses. A SEM approach has been widely employed in travel behavior research [71]. Compared to regression analysis, it has the advantages of being able to analyze constructs specified as linear combinations of the observed variables and can analyze direct and indirect relations of numerous independent and dependent variables [72].

The confirmatory factor analysis (CFA) was performed to assess the validity of the measurement model in the first step. After the CFA model was tested and validated, the structural relationships among the latent variables were analyzed. All of the analyses were done using SPSS 20.0 and AMOS 20.0 .

\subsection{Demographic Characteristics of the Respondents}

Table 1 shows the profiles of the respondents. The sample was made up of $38.7 \%$ males and $61.3 \%$ females. In terms of the respondents' age, results show that $34.8 \%$ of the respondents were aged between 31 and $40,17.8 \%$ were in their 50 s or above, $16.5 \%$ were 20 years old or below, $16.1 \%$ were between 41 and 50 years old, and $14.8 \%$ were between 21 and 30 years old. With respect to education, majority $(60 \%)$ of the respondents has an undergraduate degree, $21.7 \%$ had a senior high or technical school degree, $9.6 \%$ had a graduate degree, and $8.7 \%$ were in their junior high or below. All respondents were Taiwanese nationals. 
Table 1. Profile of respondents.

\begin{tabular}{|c|c|c|c|}
\hline \multicolumn{2}{|c|}{ Characteristics } & \multirow{3}{*}{$\begin{array}{c}\text { Frequency } \\
89 \\
141\end{array}$} & \multirow{3}{*}{$\begin{array}{c}\text { Percentage } \\
38.7 \\
61.3\end{array}$} \\
\hline Condor & Male & & \\
\hline Gender & Female & & \\
\hline \multirow{5}{*}{ Age } & 20 or below & 38 & 16.5 \\
\hline & $21-30$ & 34 & 14.8 \\
\hline & $31-40$ & 80 & 34.8 \\
\hline & $41-50$ & 37 & 16.1 \\
\hline & 50 or above & 41 & 17.8 \\
\hline \multirow{4}{*}{ Education } & Junior high or below & 20 & 8.7 \\
\hline & Senior high or technical school & 50 & 21.7 \\
\hline & Undergraduate & 138 & 60.0 \\
\hline & Graduate & 22 & 9.6 \\
\hline \multirow{8}{*}{ Occupation } & Student & 49 & 21.3 \\
\hline & Public servant & 33 & 14.3 \\
\hline & Business & 13 & 5.7 \\
\hline & Manufacturing & 10 & 4.3 \\
\hline & Agroforestry & 6 & 2.6 \\
\hline & Service & 87 & 37.8 \\
\hline & Self employed & 21 & 9.1 \\
\hline & Others & 11 & 4.8 \\
\hline \multirow{5}{*}{ Income $\left(\mathrm{NT} \${ }^{\mathrm{a}}\right)$} & $<\$ 20,000$ & 77 & 33.5 \\
\hline & $\$ 20,001 \sim \$ 30,000$ & 41 & 17.8 \\
\hline & $\$ 30,001 \sim \$ 40,000$ & 54 & 23.5 \\
\hline & $\$ 40,0001 \sim \$ 50,000$ & 34 & 14.8 \\
\hline & $\$ 50,001$ or over & 24 & 10.4 \\
\hline \multirow{4}{*}{ Travel motivation } & Recreation & 130 & 37.1 \\
\hline & Natural exploration & 95 & 27.1 \\
\hline & Relax & 84 & 24.0 \\
\hline & Increasing knowledge & 41 & 11.8 \\
\hline \multirow{2}{*}{$\begin{array}{c}\text { Experience in } \\
\text { environmental groups }\end{array}$} & Yes & 47 & 20.4 \\
\hline & No & 183 & 79.6 \\
\hline \multirow{2}{*}{$\begin{array}{l}\text { Experience in } \\
\text { environmental activities }\end{array}$} & Yes & 67 & 29.1 \\
\hline & No & 163 & 70.9 \\
\hline \multirow{2}{*}{ Ecotourism experience } & Yes & 107 & 46.5 \\
\hline & No & 123 & 53.5 \\
\hline
\end{tabular}

Note: ${ }^{a}$ One U.S. dollar equals approximately 30.0 New Taiwanese (NT) dollars.

Regarding respondents' occupation, $37.8 \%$ were in the service sector, $21.3 \%$ were students, $14.3 \%$ were public servant, and only a few respondents were self-employed $(9.1 \%)$, in business $(5.7 \%)$, other $(4.8 \%)$, manufacturing $(4.3 \%)$, and agroforestry $(2.6 \%)$. With respect to income, $33.5 \%$ of the respondents were earning below NT $\$ 20,000$ (655 USD), 23.5\% were earning between NT $\$ 30,001$ (982 USD) and NT\$40,000 (1309 USD), 17.8\% were earning between NT\$20,001 (655 USD) and NT\$30,000 (982 USD), while $25.2 \%$ were earning over NT\$40,000 (1309 USD).

Table 1 shows that $37.1 \%$ of the respondents reported that their major travel motivation to the Aogu coastal wetland was for recreation, $27.1 \%$ were for exploring nature, $24.0 \%$ were for relaxing, and $11.8 \%$ were for increasing knowledge. The respondents were also asked to indicate if they have any experiences with environmental groups, on environmental protection activities, and on ecotourism. The results indicate that only $20.4 \%$ and $29.1 \%$ of the respondents had been involved in environmental groups and environmental protection activities, respectively. In addition, $46.5 \%$ of respondents had ecotourism experiences. 


\section{Analysis and Results}

\subsection{Descriptive Statistics and Reliability Test}

The descriptive statistics, Cronbach's alphas, and corrected item-total correlation (CITC) coefficients, are shown in Table 2. Results show that support service (mean $=4.324$ ) is perceived by the tourists as the most important service function created by the Aogu coastal wetland, followed by cultural service $($ mean $=4.274)$, regulating service $($ mean $=4.218)$, and provisioning service $($ mean $=3.924)$.

Table 2. Descriptive statistics and reliability test results.

\begin{tabular}{|c|c|c|c|c|c|}
\hline Dimensions & No. of Items & Mean & S.D. & Alpha & $\begin{array}{l}\text { Range of Corrected } \\
\text { Item-Total } \\
\text { Correlation } \\
\end{array}$ \\
\hline \multicolumn{6}{|l|}{ Perceived value of wetland's } \\
\hline ecosystem services & 5 & 4.218 & 0.084 & 0.839 & $0.590-0.721$ \\
\hline \multicolumn{6}{|l|}{ Regulating service (RS) } \\
\hline Cultural service (CS) & 6 & 4.274 & 0.071 & 0.888 & $0.676-0.762$ \\
\hline Support service (SS) & 4 & 4.324 & 0.084 & 0.861 & $0.669-0.751$ \\
\hline Provisioning service (PS) & 4 & 3.924 & 0.071 & 0.926 & $0.743-0.882$ \\
\hline Environmental emotion (concern) & 6 & 4.243 & 0.130 & 0.879 & $0.608-0.770$ \\
\hline $\begin{array}{l}\text { Friendly environmental behavior } \\
\text { Indirect friendly environmental } \\
\text { behavior (IFEB) }\end{array}$ & 4 & 3.678 & 0.077 & 0.861 & $0.641-0.746$ \\
\hline $\begin{array}{l}\text { Direct friendly environmental } \\
\text { behavior (DFEB) }\end{array}$ & 5 & 4.002 & 0.130 & 0.866 & $0.586-0.759$ \\
\hline Revisit intention & 3 & 3.859 & 0.071 & 0.913 & $0.799-0.861$ \\
\hline
\end{tabular}

Cronbach's alpha statistics and corrected item-total correlation (CITC) were calculated to assess the internal consistency and reliability of the construct items. As shown in Table 2, the Cronbach alpha values of the eight factors were greater than the suggested minimum value of 0.7 , and therefore the reliability of the instrument was satisfactory [66]. In addition, CITC has been used commonly in psychology and refers to how all the items or indicators measure the same construct [73]. It is widely recommended that the items measuring the construct should have an item-total correlation of greater than 0.5 [72,73]. Results of CITC analyses, as shown in Table 2, also indicate that all CITC scores were way above 0.5 , confirming that each item was measuring the same construct.

\subsection{Measurement Model Validity}

Confirmatory factor analysis (CFA) with a multiple-indicator measurement model was performed in this study to assess the measurement theory (i.e., unidimensionality, reliability, and validity of the construct) [70]. As shown in Table 3, the CFA results imply an adequate model fit $\left(\chi^{2}=145.914\right.$, $\mathrm{df}=84, p=0.000$ ). Moreover, the goodness-of-fit indices (i.e., GFI =0.924, $\mathrm{CFI}=0.968, \mathrm{NFI}=0.929$, $\mathrm{RFI}=0.911, \mathrm{IFI}=0.968, \mathrm{TLI}=0.960)$ were way above the recommended cut-off value of 0.90 ; and RMR (0.017) and RMSEA (0.057) were below the recommended threshold of 0.08 [72,74,75]. In addition, the normed chi-square $\left(\chi^{2} / \mathrm{df}\right)$ also had a value of 1.737 , and therefore met the recommended value of less 2 for model parsimony. All these fit indices for the proposed model provide sufficient support for the measurement model to be an acceptable representation of the hypothesized constructs.

Convergent validity can be tested by checking the critical ratio (C.R.), item reliability $\left(R^{2}\right)$, and average variance extracted (AVE) estimates [72]. It is recommended that the C.R. be greater than 2.00 in its absolute value, and item reliability $\left(R^{2}\right)$ values and AVE estimates should be greater than the acceptable values $\left(R^{2}>0.3\right.$ and AVE estimate $\left.>0.5\right)[72,76,77]$. The results, as shown in Table 3, indicate that all the C.R. values were significant at the 0.05 level, all $\mathrm{R}^{2}$ values for the items are greater than 0.3 , and AVE estimates ranged from 0.547 to 0.779 , exceeding the acceptable value of at least 0.50 . Hence, all the above indices provide evidence of the convergent validity of the instrument. 
Table 3. Results of confirmatory factor analysis CFA analysis.

\begin{tabular}{|c|c|c|c|c|c|c|}
\hline Latent variables & Factors & $\begin{array}{l}\text { Unstandardized } \\
\text { Factor Loading }\end{array}$ & $\begin{array}{c}\text { Standardized } \\
\text { Factor Loading }\end{array}$ & S.D. & $\begin{array}{l}\text { Critical } \\
\text { Ratio }\end{array}$ & $\mathbf{R}^{2}$ \\
\hline \multirow{4}{*}{$\begin{array}{c}\xi 1 \\
\text { Perceived value of wetland's } \\
\text { ecosystem services }\end{array}$} & RS & 0.766 & 0.669 & 0.072 & 10.623 & 0.447 \\
\hline & CS & 0.914 & 0.802 & 0.069 & 13.184 & 0.643 \\
\hline & SS & 1.000 & 0.861 & & & 0.741 \\
\hline & PS & 0.929 & 0.598 & 0.100 & 9.286 & 0.358 \\
\hline \multirow{6}{*}{$\begin{array}{l}\eta 1 \\
\text { Environmental emotion (concern) }\end{array}$} & EE1 & 0.822 & 0.699 & 0.071 & 11.601 & 0.489 \\
\hline & EE2 & 0.977 & 0.788 & 0.071 & 13.665 & 0.621 \\
\hline & EE3 & 1.000 & 0.841 & & & 0.708 \\
\hline & EE4 & 0.797 & 0.715 & 0.067 & 11.960 & 0.511 \\
\hline & EE5 & 0.927 & 0.744 & 0.073 & 12.619 & 0.554 \\
\hline & EE6 & 0.854 & 0.661 & 0.079 & 10.797 & 0.438 \\
\hline \multirow{2}{*}{$\begin{array}{l}\eta 2 \\
\text { Friendly environmental behavior }\end{array}$} & IFEB & 1.000 & 0.757 & & & 0.572 \\
\hline & DFEB & 0.933 & 0.788 & 0.083 & 11.178 & 0.620 \\
\hline \multirow{3}{*}{$\begin{array}{c}\eta 3 \\
\text { Revisit intention }\end{array}$} & RVI1 & 0.927 & 0.864 & 0.048 & 19.459 & 0.747 \\
\hline & RVI2 & 1.000 & 0.937 & & & 0.878 \\
\hline & RVI3 & 0.959 & 0.844 & 0.052 & 18.546 & 0.713 \\
\hline
\end{tabular}

Note: RS: regulating service; CS: cultural service; SS: support service; PS: provisioning service; IFEB: indirect friendly environmental behavior; DFEB: direct friendly environmental behavior; EE1-EE6 are the items under environmental emotion (see Appendix A); RVI1-RVI3 are the items under revisit intention (see Appendix A). Model fit index: $\chi^{2}=145.914, \chi^{2} / \mathrm{df}=1.737, \mathrm{GFI}=0.924$, AGFI $=0.891, \mathrm{RMR}=0.017, \mathrm{RMSEA}=0.057, \mathrm{NFI}=0.929, \mathrm{RFI}=0.911$, $\mathrm{IFI}=0.968, \mathrm{TLI}=0.960, \mathrm{CFI}=0.968$.

The average variance extracted (AVE) estimates were then compared with the squared correlation between the constructs to assess the discriminant validity. Discriminant validity is present if the unrelated items are proven to be unrelated (Hair et al., 2010). As revealed in Table 4, the highest squared correlation was observed between friendly environmental behavior and revisit intention, and it was 0.460. This was significantly lower than their individual AVEs, which were 0.597 and 0.779 , respectively. Thus, the results show that the constructs had discriminant validity. Finally, composite reliability is an indicator of the internal consistency of the items measuring the construct and ranges between 0 to 1 [78]. The higher values of composite reliability mean that the indicator items were intercorrelated and measured the same construct. Table 4 shows that all constructs, which were greater than the 0.7 recommended value [72,74], displayed composite reliabilities.

Table 4. Discriminant validity and composite reliability.

\begin{tabular}{|c|c|c|c|c|c|}
\hline Variables & $\begin{array}{l}\text { Composite } \\
\text { Reliability }^{\text {a }}\end{array}$ & $\begin{array}{c}\xi 1 \\
\text { PVWESS }\end{array}$ & $\begin{array}{c}\eta 1 \\
\text { EM }\end{array}$ & $\begin{array}{c}\eta 2 \\
\text { FEB }\end{array}$ & $\begin{array}{c}\eta 3 \\
\text { RVI }\end{array}$ \\
\hline $\begin{array}{c}\xi 1 \\
\text { PVWESS }\end{array}$ & 0.826 & $0.547^{b}$ & & & \\
\hline $\begin{array}{c}\eta 1 \\
\text { EM }\end{array}$ & 0.881 & $\begin{array}{c}0.545 \\
(0.294)^{\mathrm{c}}\end{array}$ & 0.553 & & \\
\hline $\begin{array}{c}\eta 2 \\
\text { FEB }\end{array}$ & 0.748 & $\begin{array}{c}0.505 \\
(0.255)\end{array}$ & $\begin{array}{c}0.578 \\
(0.334)\end{array}$ & 0.597 & \\
\hline $\begin{array}{c}\eta 3 \\
\text { RVI }\end{array}$ & 0.913 & $\begin{array}{c}0.459 \\
(0.211)\end{array}$ & $\begin{array}{c}0.472 \\
(0.223)\end{array}$ & $\begin{array}{c}0.678 \\
(0.460)\end{array}$ & 0.779 \\
\hline
\end{tabular}

Note: a composite reliability $=(\text { sum of standardized loading })^{2} /\left[(\text { sum of standardized loading })^{2}+(\right.$ sum of indicator measurement error)]; indicator measurement error can be calculated as $1-$ (standardized loading) ${ }^{2} .{ }^{b}$ The AVE value is on the diagonal. ${ }^{\mathrm{c}}$ Squared correlation coefficient.

\subsection{Hypothesis Testing}

After confirming and establishing a good model fit for the proposed model, the hypothesized relationships were tested. The overall fits of the estimated model were acceptable, given that the fit indices of CFI $=0.967, \mathrm{NFI}=0.927, \mathrm{RFI}=0.908, \mathrm{IFI}=0.967$, and TLI $=0.958$ were way above the recommended value of at least 0.9 [72,75]. Moreover, the RMR (0.017) and RMSEA $(0.058)$ values were 
lower than the recommended threshold of 0.08 , and normed Chi-square $\left(\chi^{2} / \mathrm{df}=1.759\right)$ fell within the recommended range.

The results of the hypotheses testing, as illustrated in Tables 5 and 6 and Figure 3, indicate that all the hypothesized relationships were significant and in the expected direction, except for the paths from perceived value of the ecosystem services to revisit intention and environmental emotion to revisit intention. The results reveal that perceived value of ecosystem services of a coastal wetland have a significant positive impact on environmental emotion ( $ß$ estimate $=0.640, C . R .>1.96$ ) and friendly environmental behavior ( $($ estimate $=0.318$, C.R. $>1.96$ ).

Table 5. Results of structural equation modeling.

\begin{tabular}{ccccccc}
\hline Paths & Estimate & S. E. $^{\mathbf{a}}$ & C.R. $^{\mathbf{b}}$ & $\mathbf{p}$ & Sign & Supported \\
\hline PVWESS -> EM & 0.640 & 0.091 & 8.575 & 0.000 & + & Supported \\
PVWESS -> FEB & 0.318 & 0.105 & 3.342 & 0.000 & + & Supported \\
PVWESS -> RVI & 0.059 & 0.143 & 0.631 & 0.528 & + & Not Supported \\
EM -> FEB & 0.506 & 0.088 & 5.258 & 0.000 & + & Supported \\
EM -> RVI & -0.134 & 0.136 & -1.234 & 0.217 & - & Not Supported \\
FEB -> RVI & 0.874 & 0.196 & 6.125 & 0.000 & + & Supported \\
\hline
\end{tabular}

Note: Model fit index: $\chi^{2}=147.776, \chi^{2} / \mathrm{df}=1.759$, GFI $=0.923$, AGFI $=0.890$, RMR $=0.017$, RMSEA $=0.058$, $\mathrm{NFI}=0.927, \mathrm{RFI}=0.908, \mathrm{IFI}=0.967, \mathrm{TLI}=0.958, \mathrm{CFI}=0.967$. ${ }^{\text {a }}$ Standard error; ${ }^{\mathrm{b}}$ Critical ratio.

Table 6. Mediation analysis results.

\begin{tabular}{ccccc}
\hline Paths & Estimate & $\boldsymbol{t}$-Value (Lower and Upper Bound) & $\boldsymbol{p}$ & Supported \\
\hline PVESS -> FEB -> RVI & 0.406 & $0.119-0.766$ & 0.009 & Supported \\
EM -> FED -> RVI & 0.625 & $0.304-1.219$ & 0.001 & Supported \\
\hline
\end{tabular}

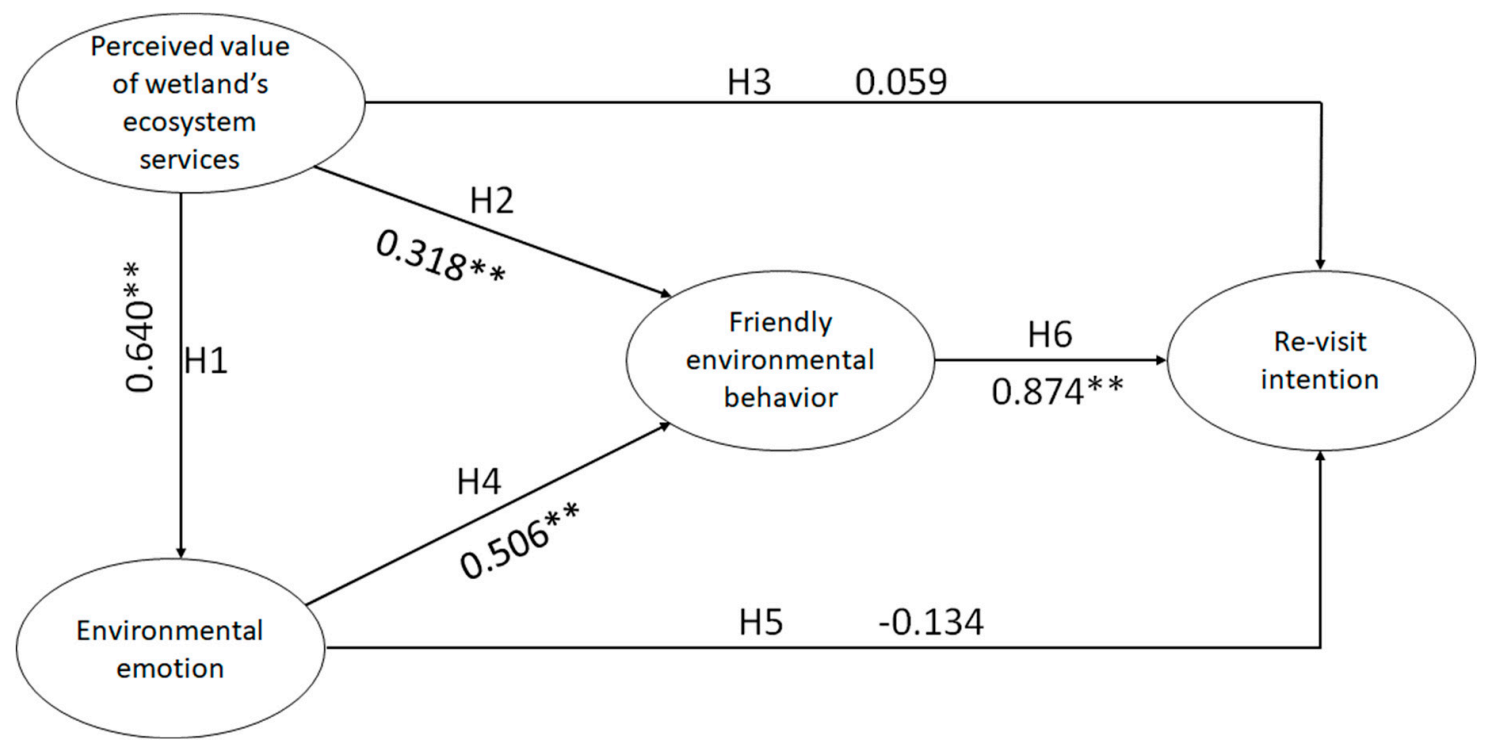

Figure 3. Results of structural model (** significant at $p<0.001)$.

The environmental emotion ( $ß$ estimate $=0.506, C . R .>1.96)$ was found to have a significant positive influence on friendly environmental behavior. Results also show that friendly environmental behavior ( $ß$ estimate $=0.874$, C.R. $>1.96$ ) has a significant positive influence on revisit intention to the Aogu coastal wetland. It also mediates the relationship between perceived value of the ecosystem services and revisit intention ( $B$ estimate $=0.406, t$ value $=0.119-0.766)$ and between environmental emotion and revisit intention ( $ß$ estimate $=0.625, t$ value $=0.304-1.219)$ 
However, there is a lack of support for significant positive relationship between the perceived value of the ecosystem service ( $B$ estimate $=0.059, C . R .<1.96)$ and revisit intention, as well as the relationship between environmental emotion ( $($ estimate $=-0.134, C . R .>-1.96)$ and revisit intention.

\section{Discussion}

This study set up a model based on the theory of planned behavior to explain revisit intentions via tourists' perceived value of wetlands' ecosystem services, tourist environmental emotion or concern, and tourists' friendly environmental behavior. Results derived from the structural equation modeling (SEM) show that a positive significant relationship was found between the perceived value of the ecosystem service and environmental emotion $\left(\mathrm{H}_{1}\right)$, as well as between the perceived value of the ecosystem service and friendly environmental behavior $\left(\mathrm{H}_{2}\right)$. This implies that a higher level of perceived value on wetland can strengthen tourists' attitude toward protecting the environment and can strengthen their environmental emotion or concern and sensitivity towards the environment. These results are consistent with the research findings of [21,49].

Moreover, a higher level of tourists' environmental emotion would lead to more friendly environmental behavior $\left(\mathrm{H}_{4}\right)$. This implies that a positive environmental emotion or a positive feeling generated from visiting an ecosystem site will enhance the tourists' friendly environmental behavior. This result is supported by the study conducted by Cheng and Wu [60], which showed that the concern and respect of tourists gained from visiting an ecotourism site affect their attitude and affection towards the environment, leading to friendly environmental behavior.

This study also reveals that friendly environmental behavior positively promotes tourists' revisit intention $\left(\mathrm{H}_{6}\right)$. Previous studies such as those of Clark, Mulgrew, Kannis-Dymand, Schaffer and Hoberg [18]; Goh and Ritchie [19]; and Han [20] showed that the determinants of intention and attitude towards behavior significantly increase when tourists are aware of the environmental problems and this awareness increases their intention to do pro-environmental actions. Thus, revisit intention will increase should friendly environmental behavior be promoted via environmental emotion or concern and perceived value, thus supporting the claim of TPB. Accordingly, perceived value should be emphasized as an antecedent to influence tourist environmental emotion or concern and tourists' friendly environmental behavior. Moreover, the positive influence of perceived value and environmental emotions on revisit intention is explained by friendly environmental behavior. Therefore, for perceived value and environmental emotion to influence revisit intention, tourists should be able to exhibit or experience friendly environmental behavior.

These relationships are mediated by friendly environmental behavior. This implies that the positive influence of this study, on the basis of TPB, sets up a framework to explain the predictors of revisit intention of tourists, which is considered as the behavioral intention in this context. According to the said theory, behavioral intentions are influenced by a combination of subjective norms, attitudes towards the behavior, and perceived behavioral control [6]. The framework shows various pathways through which revisit intention can be achieved after the travel experience of tourists. Tourists visit ecological areas (i.e., wetlands) due to the perceived value obtained. As mentioned, wetlands offer ecosystem services, such as climate regulation, as an agent for creating other ecosystem services, provisioning services, and cultural services. Aogu Wetland Forest Park in Taiwan is made up of wetlands, fish farms, sandbars, farms, and plantation and has been designated as an important wildlife territory [79]. Thus, when tourist agencies offer the said services, in the context of wetlands, that enhance a tourist's environmental emotion or concern leading to friendly environmental behavior, revisit intention will occur. Further, when the level of friendly environmental behavior is increased, thus increasing their attitude towards that behavior, revisit intention will also increase. This model emphasizes that perceived value or behavioral belief, when the attitude towards the perceived value is increased through friendly environmental behavior, leads to increased behavioral intention. 


\section{Conclusions}

Ecotourism offers tourists a recreational experience, while at the same time promoting environmental sustainability. To ensure revisit intention, it is important to understand its predictors. When tourists perceive a value in the services or benefits offered by an ecotourist destination, they gain higher environmental emotion or concern, which leads them to engage in friendly environmental behavior and subsequently increase their intention to revisit the area. Thus, tourist managers should educate tourists on the various services offered by wetlands, as wetlands are one of the most productive ecosystems and play an important role in flood control, shoreline and storm protection, carbon sink and source, among others. This strategy increases the awareness of the tourists on the perceived value of an ecosystem and would thereby increase their environmental concern and friendly environmental behavior. However, tourist managers should focus, aside from increasing the tourists' perceived value of an ecotourist destination, on enhancing the tourists' friendly environmental behaviors to enhance their revisit intention. Ecotourism packages should be designed such that they increase the perceived value of an ecotourist destination and enhance friendly environmental behavior. Ecotourism is a booming trend in the travel industry, but tourists are not often aware of the value of ecosystem services and friendly or responsible environmental behavior. Thus, there should be an emphasis on the management of ecosystem services to provide an authentic nature experience for the tourists, while strengthening their behavior towards responsible ecotourism.

One of the limitations of this study is that it used convenience sampling due to limited resources. The results might have been different if another sampling method was utilized. Moreover, an experimental, mixed method, or longitudinal design might be helpful to advance this line of research.

This study was conducted in Aogu wetlands in Taiwan. Other ecotourist destination areas could be tested and the impact of the frequency of ecotravels could be explored to enhance the generalizability of the results. Accordingly, moderating and mediating variables could be added in the proposed model to determine the predictors of revisit intentions for ecotourist destinations. Other determinants of behavioral intentions not considered in this study can also be explored. Further, this study tested the model for Taiwanese nationals. Future studies can consider foreign visitors to assess the predictive power of the study's framework, since TPB can also be used to evaluate behavioral intentions across cultures [80].

Author Contributions: Conceptualization and data collection, writing—draft preparation: M.-T.L., methodology and statistical analysis, writing - draft preparation: J.-M.L., writing — draft preparation, review and editing: E.Q.B. All authors have read and agreed to the published version of the manuscript.

Funding: This work was partially supported by the Ministry of Science and Technology in Taiwan under research grant number: MOST 108-2221-E-992-022.

Acknowledgments: The authors greatly appreciate Jia-Rong Chou for her assistance in data collection and Ching-Chiao Yang for his substantial comments to improve the manuscript.

Conflicts of Interest: The authors declare no conflict of interest.

\section{Appendix A}

Questionnaire

Regulating service

1. Slow down the erosion and destruction of the coast.

2. Precipitate and filter pollutants produced by humans (such as industrial wastewater).

3. Helps regulate flooding on land.

4. Contribute to the regulation of gases (such as mangrove plants to absorb carbon dioxide to release oxygen).

5. Can conserve groundwater.

Cultural service 
1. Provide recreational service (such as ecotourism).

2. Contribute to art and literature (such as literary creation, photography, and painting).

3. Provides connection between people and their culture.

4. Form unique cultural and customary practices (such as raising babies, etc.).

5. Provides environmental education.

6. Provides science research opportunities.

Support service

1. Protect marine and terrestrial animal and plant resources.

2. Provide habitat for living things.

3. Increase primary productivity (e.g., photosynthesis produces food sources for animals).

4. Maintain marine biodiversity.

Provisioning service

1. Provide human food and nutrient sources (such as fish and shellfish).

2. Provide sources of raw materials (such as algae, minerals) for daily necessities.

3. Provide sources of man-made medicines (such as algae, chitin, and cod liver oil).

4. Contains energy (such as peat, etc.).

Environmental emotion

1. I am worried about the deterioration of the quality of the natural environment.

2. I am angry that the wetlands have been cut down and replanted into cash crops.

3. I am worried about the development of natural areas that will affect the endangered species of wild animals.

4. I think it is unethical to pollute the ecosystem and environment here.

5. I was angry when I saw tourists picking flowers and trees, collecting shells, and catching fiddle crabs.

6. I am troubled by the fact that people cannot contribute to the environment.

Indirect friendly environmental behavior

1. I will stop when I see a visitor destroying the environment, and I will promote the concept of environmental conservation to my peers.

2. I am willing to contribute to improve the quality of the environment.

3. I will participate in environmental protection activities to maintain the environmental quality of natural areas (such as ecotourism).

4. I will support actions such as protests and call on relevant units to pay attention to environmental issues.

Direct friendly environmental behavior

1. I support implementing partition management.

2. I will support user-paid requirements (such as eco-taxes, etc.).

3. In order to reduce the environmental load, I support the implementation of seed quantity control.

4. I support requiring environmental protection cost from the local residents.

5. I support that business operators comply with the ecological and environmental protection law (such as the standard of the label system, low carbon certification).

Revisit Intention

1. I will recommend wetland-related activities to relatives and friends.

2. I will promote the wetland-related activities.

3. I will participate in wetland-related activities next time. 


\section{References}

1. UNWTO. World Tourism Barometer Nº18 JANUARY 2020. Available online: https://www.unwto.org/worldtourism-barometer-n18-january-2020 (accessed on 6 July 2020).

2. UNWTO. International Tourist Arrivals Could Fall by $20-30 \%$ in 2020. Available online: https://www.unwto. org/news/international-tourism-arrivals-could-fall-in-2020 (accessed on 6 July 2020).

3. WTTC. Economic Impact Reports. Available online: https://wttc.org/Research/Economic-Impact (accessed on 6 July 2020).

4. WTTC. Taiwan, China 2020 Annual Research: Key Highlights. Available online: https://www.wttc.org/ economic-impact/country-analysis/country-data/ (accessed on 6 July 2020).

5. Fransson, N.; Garling, T. Environmental concern: Conceptual definitions, measurement methods, and research findings. J. Environ. Psychol. 1999, 19, 369-382. [CrossRef]

6. Ajzen, I. The theory of planned behavior. Organ. Behav. Hum. Decis. Process. 1991, 50, 179-211. [CrossRef]

7. Fishbein, M.; Ajzen, I. Belief, Attitude, Intention, and Behavior: An Introduction to Theory and Research; Addison-Wesley: Reading, MA, USA, 1975.

8. Zeithaml, V. Consumer Perceptions of Price, Quality and Value: A Means-End Model and Synthesis of Evidence. J. Mark. 1988, 52, 2-22. [CrossRef]

9. Björk, P. Ecotourism from a conceptual perspective, an extended definition of a unique tourism form. Int. J. Tour. Res. 2000, 2, 189-202. [CrossRef]

10. International Ecological Society. 9th INTECOL International Wetlands Conference Proceedings. Available online: https://conference.ifas.ufl.edu/intecol/Program_BOOK.pdf (accessed on 18 June 2020).

11. Millenium Ecosystem Assessment. Ecosystems and Human Well-Being: Wetlands and Water. Available online: https://www.millenniumassessment.org/documents/document.358.aspx.pdf (accessed on 18 March 2020).

12. Think Global Green Organization. Wetlands. Available online: https://thinkglobalgreen.org/wetlands/ (accessed on 5 May 2020).

13. LaMorte, W. The Theory of Planned Behavior. Available online: http://sphweb.bumc.bu.edu/otlt/MPHModules/SB/BehavioralChangeTheories/BehavioralChangeTheories3.html (accessed on 18 June 2020).

14. Ajzen, I.; Driver, B. Application of the Theory of Planned Behavior to Leisure Choice. J. Leisure Res. 1992, 24, 207-224. [CrossRef]

15. Reibstein, D.; Lovelock, C.; Dobson, R. The Direction of Causality Between Perceptions, Affect, and Behavior: An Application to Travel Behavior. J. Consum. Res. 1980, 6, 370-376. [CrossRef]

16. Miller, Z.D. The Enduring Use of the Theory of Planned Behavior. Hum. Dimens. Wildl. 2017, 22, 583-590. [CrossRef]

17. Armitage, C.J.; Conner, M. Efficacy of the Theory of Planned Behaviour: A meta-analytic review. Br. J. Soc. Psychol. 2001, 40, 471-499. [CrossRef]

18. Clark, E.; Mulgrew, K.; Kannis-Dymand, L.; Schaffer, V.; Hoberg, R. Theory of planned behaviour: Predicting tourists' pro-environmental intentions after a humpback whale encounter. J. Sustain. Tour. 2019, 27, 649-667. [CrossRef]

19. Goh, E.; Ritchie, B. Using the Theory of Planned Behavior to Understand Student Attitudes and Constraints Toward Attending Field Trips. J. Teach. Travel Tour. 2011, 11, 179-194. [CrossRef]

20. Han, H. Travelers' pro-environmental behavior in a green lodging context: Converging value-belief-norm theory and the theory of planned behavior. Tour. Manag. 2015, 47, 164-177. [CrossRef]

21. Chiu, Y.-T.H.; Lee, W.-I.; Chen, T.-H. Environmentally responsible behavior in ecotourism: Antecedents and implications. Tour. Manag. 2014, 40, 321-329. [CrossRef]

22. Vroom, V.H. Work and Motivation; Wiley: New York, NY, USA, 1964.

23. Chan, L.; Kim, J.; Baum, T. Ecotourists' Perception of Ecotourism Experience in Lower Kinabatangan, Sabah, Malaysia. J. Sustain. Tour. 2007, 15, 574-590. [CrossRef]

24. Diaz-Christiansen, S.; Lopez-Guzman, T.; Pérez Gálvez, J.; Muñoz-Fernández, G. Wetland tourism in natural protected areas: Santay Island (Ecuador). Tour. Manag. Perspect. 2016, 20, 47-54. [CrossRef]

25. Park, E.; Lee, S.; Peters, D.J. Iowa wetlands outdoor recreation visitors' decision-making process: An extended model of goal-directed behavior. J. Outdoor Recreat. Tour. 2017, 17, 64-76. [CrossRef]

26. Lee, T.H.; Hsieh, H.-P. Indicators of sustainable tourism: A case study from a Taiwan's wetland. Ecol. Ind. 2016, 67, 779-787. [CrossRef] 
27. Boyd, J.; Banzhaf, S. What are ecosystem services? The need for standardized environmental accounting units. Ecol. Econ. 2007, 63, 616-626. [CrossRef]

28. Weinstein, A.; Johnson, W.C. Designing and Delivering Superior Customer Value: Concepts, Cases, and Applications; St. Lucie Press: Boca Raton, FL, USA, 1999.

29. Sweeney, J.C.; Soutar, G.N.; Johnson, L.W. The role of perceived risk in the quality-value relationship: A study in a retail environment. J. Retail. 1999, 75, 77-105. [CrossRef]

30. Baker, W.E.; Sinkula, J.M. The synergistic effect of market orientation and learning orientation on organizational performance. J. Acad. Mark. Sci. 1999, 27, 411-427. [CrossRef]

31. Laroche, M.; Bergeron, J.; Barbaro-Forleo, G. Targeting consumers who are willing to pay more for environmentally friendly products. J. Consum. Mark. 2001, 18, 503-520. [CrossRef]

32. Raeisi, A.; Bijani, M.; Chizari, M. The mediating role of environmental emotions in transition from knowledge to sustainable use of groundwater resources in Iran's agriculture. Int. Soil Water Conserv. Res. 2018, 6, 143-152. [CrossRef]

33. Meng, B.; Cui, M. The role of co-creation experience in forming tourists' revisit intention to home-based accommodation: Extending the theory of planned behavior. Tour. Manag. Perspect. 2020, 33, 100581. [CrossRef]

34. Meng, B.; Choi, K. An investigation on customer revisit intention to theme restaurants: The role of servicescape and authentic perception. Int. J. Contemp. Hosp. Manag. 2018, 30, 1646-1662. [CrossRef]

35. Japutra, A.; Loureiro, S.M.C.; Molinillo, S.; Ekinci, Y. Travellers' mindsets and theory of planned behaviour. Tour. Manag. Perspect. 2019, 30, 193-196. [CrossRef]

36. Goh, E.; Ritchie, B.; Wang, J. Non-compliance in national parks: An extension of the theory of planned behaviour model with pro-environmental values. Tour. Manag. 2017, 59, 123-127. [CrossRef]

37. Eccles, J.S.; Wigfield, A. From expectancy-value theory to situated expectancy-value theory: A developmental, social cognitive, and sociocultural perspective on motivation. Contemp. Educ. Psychol. 2020, 61, 101859. [CrossRef]

38. Loh, E.K.Y. What we know about expectancy-value theory, and how it helps to design a sustained motivating learning environment. System 2019, 86, 102119. [CrossRef]

39. Poort, I.; Jansen, E.; Hofman, A. Intercultural group work in higher education: Costs and benefits from an expectancy-value theory perspective. Int. J. Educ. Res. 2019, 93, 218-231. [CrossRef]

40. Hsu, C.; Cai, L.; Li, M. Expectation, Motivation, and Attitude: A Tourist Behavioral Model. J. Travel Res. 2010, 49, 282-296. [CrossRef]

41. Kiatkawsin, K.; Han, H. Young travelers' intention to behave pro-environmentally: Merging the value-belief-norm theory and the expectancy theory. Tour. Manag. 2017, 59, 76-88. [CrossRef]

42. Castellanos-Verdugo, M.; Vega-Vázquez, M.; Oviedo-García, M.Á.; Orgaz-Agüera, F. The relevance of psychological factors in the ecotourist experience satisfaction through ecotourist site perceived value. J. Clean. Prod. 2016, 124, 226-235. [CrossRef]

43. Prebensen, N.; Woo, E.; Chen, J.; Uysal, M. Motivation and Involvement as Antecedents of the Perceived Value of the Destination Experience. J. Travel Res. 2013, 52, 253-264. [CrossRef]

44. Woodruff, R.B. Customer value: The next source for competitive advantage. J. Acad. Mark. Sci. 1997, $25,139$. [CrossRef]

45. Petrick, J.F. The Roles of Quality, Value, and Satisfaction in Predicting Cruise Passengers' Behavioral Intentions. J. Travel Res. 2004, 42, 397-407. [CrossRef]

46. Zhang, H.; Lei, S.L. A structural model of residents' intention to participate in ecotourism: The case of a wetland community. Tour. Manag. 2012, 33, 916-925. [CrossRef]

47. Sun, B.; Cui, L.; Li, W.; Kang, X.; Pan, X.; Lei, Y. A meta-analysis of coastal wetland ecosystem services in Liaoning Province, China. Estuar. Coast. Shelf Sci. 2018, 200, 349-358. [CrossRef]

48. Lee, T.H.; Jan, F.-H.; Yang, C.-C. Conceptualizing and measuring environmentally responsible behaviors from the perspective of community-based tourists. Tour. Manag. 2013, 36, 454-468. [CrossRef]

49. Han, J.; Lee, M.; Hwang, Y.-S. Tourists' Environmentally Responsible Behavior in Response to Climate Change and Tourist Experiences in Nature-Based Tourism. Sustainability 2016, 8, 644. [CrossRef]

50. Stern, P. Toward a Coherent Theory of Environmentally Significant Behavior. J. Soc. Issues 2000, 56, 407-424. [CrossRef] 
51. Chaulagain, S.; Wiitala, J.; Fu, X. The impact of country image and destination image on US tourists' travel intention. J. Destin. Mark. Manag. 2019, 12,1-11. [CrossRef]

52. Wang, W.; Chen, J.S.; Fan, L.; Lu, J. Tourist experience and Wetland parks: A case of Zhejiang, China. Ann. Tour. Res. 2012, 39, 1763-1778. [CrossRef]

53. Oviedo-García, M.Á.; Vega-Vázquez, M.; Castellanos-Verdugo, M.; Orgaz-Agüera, F. Tourism in protected areas and the impact of servicescape on tourist satisfaction, key in sustainability. J. Destin. Mark. Manag. 2019, 12, 74-83. [CrossRef]

54. Lee, S.; Jeon, S.; Kim, D. The impact of tour quality and tourist satisfaction on tourist loyalty: The case of Chinese tourists in Korea. Tour. Manag. 2011, 32, 1115-1124. [CrossRef]

55. Quintal, V.A.; Thomas, B.; Phau, I. Incorporating the winescape into the theory of planned behaviour: Examining 'new world' wineries. Tour. Manag. 2015, 46, 596-609. [CrossRef]

56. Hsu, C.H.C.; Huang, S. An Extension of the Theory of Planned Behavior Model for Tourists. J. Hosp. Tour. Res. 2010, 36, 390-417. [CrossRef]

57. Zhang, J.; Yu, P.; Hu, H. The theory of planned behavior as a model for understanding tourists' responsible environmental behaviors: The moderating role of environmental interpretations. J. Clean. Prod. 2018, 194. [CrossRef]

58. Su, L.; Hsu, M.K.; Boostrom, R.E. From recreation to responsibility: Increasing environmentally responsible behavior in tourism. J. Bus. Res. 2020, 109, 557-573. [CrossRef]

59. Zeppel, H. Education and Conservation Benefits of Marine Wildlife Tours: Developing Free-Choice Learning Experiences. J. Environ. Educ. 2008, 39, 3-18. [CrossRef]

60. Cheng, T.-M.; Wu, H.C. How do environmental knowledge, environmental sensitivity, and place attachment affect environmentally responsible behavior? An integrated approach for sustainable island tourism. J. Sustain. Tour. 2015, 23, 557-576. [CrossRef]

61. Han, H.; Back, K.-J.; Barrett, B. Influencing factors on restaurant customers' revisit intention: The roles of emotions and switching barriers. Int. J. Hosp. Manag. 2009, 28, 563-572. [CrossRef]

62. Akgün, A.; Ayar, H.; Keskin, H.; Onal, I. The relationships among nostalgic emotion, destination images and tourist behaviors: An empirical study of Istanbul. J. Destin. Mark. Manag. 2019, 16, 100355. [CrossRef]

63. Servidio, R.; Ruffolo, I. Exploring the relationship between emotions and memorable tourism experiences through narratives. Tour. Manag. Perspect. 2016, 20, 151-160. [CrossRef]

64. Ballantyne, R.; Packer, J.; Falk, J. Visitors' learning for environmental sustainability: Testing short- and long-term impacts of wildlife tourism experiences using structural equation modelling. Tour. Manag. 2011, 32, 1243-1252. [CrossRef]

65. Fazio, R.H. Multiple processes by which attitudes guide behavior: The mode model as an integrative framework. In Advances in Experimental Social Psychology; Elsevier: Amsterdam, The Netherlands, 1990.

66. Iacobucci, D.; Churchill, G.A. Marketing Research: Methodological Foundations; Cengage Learning: Mason, $\mathrm{OH}$, USA, 2010.

67. Kollmuss, A.; Agyeman, J. Mind the Gap: Why Do People Act Environmentally and What Are the Barriers to Pro-Environmental Behavior? Environ. Educ. Res. 2002, 8, 239-260. [CrossRef]

68. Google. Google Maps: Aogu Wetlands and Forest Park. 1192. Available online: https://www.google.com/maps/ place/Aogu+Wetlands+and+Forest+Park/@24.048986,119.2532914,8.27z/data=!4m5!3m4!1s0x346c274bfffffff: 0xbef3739aa64ec5af!8m2!3d23.5064272!4d120.1192432 (accessed on 25 June 2020).

69. Podsakoff, P.M.; MacKenzie, S.B.; Podsakoff, N.P. Sources of Method Bias in Social Science Research and Recommendations on How to Control It. Annu. Rev. Psychol. 2012, 63, 539-569. [CrossRef] [PubMed]

70. Anderson, J.C.; Gerbing, D.W. Structural equation modeling in practice: A review and recommended two-step approach. Psychol. Bull. 1988, 103, 411-423. [CrossRef]

71. Golob, T.F. Structural equation modeling for travel behavior research. Transp. Res. Part B Methodol. 2003, 37, 1-25. [CrossRef]

72. Hair, J.; Black, W.; Babin, B.; Anderson, R. Multivariate Data Analysis; Prentice Hall: Upper Saddle River, NJ, USA, 2019.

73. Koufteros, X.A. Testing a model of pull production: A paradigm for manufacturing research using structural equation modeling. J. Oper. Manag. 1999, 17, 467-488. [CrossRef]

74. Bagozzi, R.; Yi, Y. On the Evaluation of Structure Equation Models. J. Acad. Mark. Sci. 1988, 16, 74-94. [CrossRef] 
75. Hu, L.t.; Bentler, P.M. Cutoff criteria for fit indexes in covariance structure analysis: Conventional criteria versus new alternatives. Struct. Equ. Model. Multidiscip. J. 1999, 6, 1-55. [CrossRef]

76. Fornell, C.; Larcker, D.F. Evaluating Structural Equation Models with Unobservable Variables and Measurement Error. J. Mark. Res. 1981, 18, 39-50. [CrossRef]

77. Yang, C.; Nay, S.; Hoyle, R.H. Three Approaches to Using Lengthy Ordinal Scales in Structural Equation Models: Parceling, Latent Scoring, and Shortening Scales. Appl. Psychol. Meas. 2010, 34, 122-142. [CrossRef] [PubMed]

78. Churchill, G.A. A Paradigm for Developing Better Measures of Marketing Constructs. J. Mark. Res. 1979, 16, 64-73. [CrossRef]

79. Forestry Bureau, T. Aogu Wetlands Forest Park. Available online: https://www.forest.gov.tw/EN/0000211 (accessed on 6 July 2020).

80. Santamaría, A.; De la Mata-Benítez, M.; Hansen, T.; Ruiz, L. Cultural Self-Construals of Mexican, Spanish, and Danish College Students: Beyond Independent and Interdependent Self. J. Cross Cult. Psychol. 2010, 41, 471-477. [CrossRef]

(C) 2020 by the authors. Licensee MDPI, Basel, Switzerland. This article is an open access article distributed under the terms and conditions of the Creative Commons Attribution (CC BY) license (http://creativecommons.org/licenses/by/4.0/). 